\title{
How Does Organisational ICT Implementation Affect E-Commerce Potential? Empirical Evidence from Serbia
}

DOI: 10.7595/management.fon.2021.0037

\begin{abstract}
:
Research Question: This study investigates both direct and indirect effects of employee ICT skills on business e-commerce potential, evaluated through e-commerce website functionality. Motivation: The study aims at expanding the existing knowledge regarding organisational ICT implementation by investigating the relation with e-commerce potential. Idea: The main idea of the paper is to understand how e-commerce potential can be improved by developing the digital skills of employees, mainly in the context of the implementation of cloud computing, portable technologies and e-commerce outsourcing. Data: A sample of 238 businesses from Serbia was considered. Responses were gathered by the Statistical Office of the Republic of Serbia, using EUROSTAT-based questionnaire. Tools: Confirmatory factor analysis and covariancebased structural equation modelling were employed for data analysis. Baron-Kenny approach was used for assessing the mediation effects in the model. Findings: Employee ICT skills showed no direct influence, but were found to have an indirect effect on e-commerce website functionality, which is manifested through organisational implementation of cloud computing and portable technologies. Findings to a certain extent suggest that certain differences between companies from transition and developing economies exist, especially regarding cloud technology adoption. Outsourcing of certain e-commerce activities showed no link with employee ICT skills, but was identified as the most influential factor in website e-commerce facilitation. Contribution: This study contributes to ICT use and e-commerce development literature, as it is the first one to investigate the direct and indirect relation between organisational ICT implementation and website e-commerce potential.
\end{abstract}

Keywords: e-commerce potential, organisational ICT implementation, e-commerce website functionality

JEL Classification: L22, M15, M54

\section{Introduction}

As the market paradigm shifts towards Industry 4.0 (Ibarra et al., 2018), digitalisation of activities and processes behind online customer touchpoints is set to become a vital predisposition in achieving organisational efficiency and efficacy (lyanda \& Ojo, 2008). Businesses are constantly being challenged to create seamless customer experience, driven by modern market demands (Picot-Coupey et al., 2016). These market shifts are especially difficult to cope with for companies operating in transition economies (Nowinski and Rialp, 2013). As more and more businesses are developing digital sales channels, market success is being determined by the level of synergy between physical and digital resources (Kabadayi, 2008). COVID-19 pandemic has only accelerated the already present trend of moving customers away from contact with the seller, to a safer, digital shopping channel (Li et al., 2020).

Nowadays, businesses have ample digital resources at their disposal for facilitating market demand for online purchasing. These include some common ones, such as PC, internet, intranet and mobile phones (Ongori \& Migiro, 2010); more developed ones, such as various software, as well as complex internet 
applications, like websites and e-shops (Mwantimwa, 2019). Consequently, information communications technologies (ICTs) are constantly gaining in organisational importance, especially when complemented by "big data" (Ibarra, et al., 2018). Organisational capacity is very important in this context, since resource limitations usually dictate the potential of various ICT applications (Kabongo \& Okpara, 2014).

Effective and efficient conduct of digital activities implies not just the availability of ICTs, but also the intensity of their usage (Dittes et al., 2019). The majority of contemporary literature which analyses ICT-related factors influencing website features and functionality does so from either a technology-oriented or a customer-oriented standpoint (Chen et al., 2017). The organisational aspect is oftentimes neglected in this context, even though it is essential for implementing digital technologies in modern businesses (Giotopoulos et al., 2017).

Implementation of ICTs represents a modern development driver in transition economies (Nowinski \& Rialp, 2013), which is why digitalisation of commercial activities is especially important for businesses coming from transition markets. Market reality has led to corporate website becoming an unavoidable part of every digital marketing mix, evolving from a promotional instrument to a significant online revenue driver (Chiou et al., 2010). Websites and e-shops are oftentimes the main facilitators of B2C and B2B e-commerce transactions (Nilashi et al., 2016; Chen et al., 2017). For a vast number of companies operating in transitioning markets, e-commerce represents a go-to digital business model, in which functionality of e-commerce websites has been identified as the key market success predictor (Ramayah et al., 2016). Website e-commerce potential is denoted by the presence of certain features, such as personalisation, customisation, order processing and tracking capacity at an organisational level (Cullen \& Taylor, 2009).

Research on e-commerce activities and related ICT implementation is present in literature (Saffu, Walker and Hinson, 2008), although lacking in terms of e-commerce potential, more specifically e-commerce website functionality. This gap is especially emphasized for papers oriented towards transition markets. This paper addresses the identified research gap, and investigates the effect of organisational ICT implementation, observed through both the human and technological perspective, on business e-commerce potential.

The aim of the study was to examine the relation between organisational ICT implementation, including both ICT presence and the intensity of usage, and the capacity of B2B and B2C websites to facilitate e-commerce activities. Employee digital skills were identified as the key human aspect of organisational ICT implementation (Yunis et al., 2012; Colombo et al., 2019) affecting the corporate e-commerce website functionality. In order to incorporate the organisational perspective into the analysis, the levels of usage of various modern ICTs, such as cloud computing, portable technologies and e-commerce outsourcing were introduced into the conceptual model and observed as potential mediators. Analysis was performed on hard data provided by the Statistical Office of the Republic of Serbia (SORS), bearing in mind that Serbia is recognized as a characteristic example of a market in transition (Kapoulas \& Ratkovic, 2015).

The contribution of this paper is twofold, having both theoretical and practical implications. First, the existing knowledge is extended, as this research, to the best of our knowledge, represents the only paper empirically investigating the effect of organisational ICT implementation on website e-commerce potential. The paper also provides a significant theoretical contribution in the sense that it covers both direct and indirect effects of employee digital skills on developing business e-commerce potential, as well as organisational roles of various ICTs within this process. Second, derived results also possess practical value as they provide a useful insight for managers into which ICT implementation directions yield highest benefits in terms of facilitating website e-commerce activities, depending on the company size. Additionally, the paper also opens certain discussion points regarding the differences between businesses from transition economies and developed markets in terms of ICT implementation approach and corresponding effect on e-commerce website functionality.

The paper is structured as follows. First, an insight into the contemporary literature is provided, followed by the research design. The next section covers the derived results, which are then later discussed. The final section of the paper contains concluding remarks, as well as research limitations.

\section{Literature Review}

Businesses located in transition economies are striving to switch from mono to multiple-channel business models by integrating digital channels into existing physical store networks in order to cope with the competitors from developed economies and their superior levels of e-commerce performance (Salciuviene et al., 
2011). In this sense, brick-and-click and pure-click companies from transition markets are under pressure to fully utilise their ICT potential when developing respective e-commerce business models.

ICTs can be defined as a compilation of data gathering, analysis and dissemination technologies (Ongori \& Migiro, 2010; Hanclova et al., 2014). For businesses to fully reap the potential benefits of ICT use, they must go beyond attaining the newest ICTs, equally focusing on their organisational adoption (Mwantimwa, 2019). This however should not be taken lightly, since ICT implementation in an existing organisational structure poses a significant challenge, due to many internal barriers and obstructions (Kabongo \& Okpara, 2014), especially for businesses operating in transition markets (Nowinski and Rialp, 2013).

\subsection{Approaches to organisational ICT implementation}

Contemporary literature on ICT implementation is plentiful and highly diversified. In their research on ICT adoption, Shiels et al. (2003) analysed technical (ICT tools) and operational (ICT introduction) aspects. Polder et al. (2018), on the other hand, observed the relation between ICT intensity (ICT capital) and productivity. Similarly, Lefophane and Kalaba (2021) also investigated the effect of ICT intensity on productivity, employment in South Africa. Other authors approached the topic by analysing the human aspect of ICT adoption and use (Giotopoulos et al., 2017). An important step in a comprehensive analysis of relevant ICT implementation aspects was taken by Cuevas-Vargas et al. (2016) by making a clear distinction between organisational, human and relationship aspects when observing ICT use. Similarly, Ongori and Migiro (2010) distinguished between human component and infrastructure as two most important aspects in ICT adoption by SMEs. Although not as numerous, papers on ICT adoption in developing countries also approach the topic from different angles, such as motivation for ICT implementation in Botswana (lyanda \& Ojo, 2008) or ICT possession in Congolese SMEs (Kabongo \& Okpara, 2014).

The present literature heterogeneity regarding organisational ICT implementation is summed up by findings by Cuevas-Vargas et al. (2016) and Ongori and Migiro (2010), who show us that it is important to differentiate between the human and infrastructural (technological) aspects of an overall organisational ICT implementation. It is generally accepted that ICT implementation in organisations improves information exchange with other stakeholders (Ongori \& Migiro, 2010), especially during marketing, promotion and sales of products and services (Mwantimwa, 2019). In this sense, from the human perspective of ICT implementation, employee ICT skills are seen as the ability and potential of employees to use available ICT tools for data exchange and communication (Colombo et al., 2019). Although certain authors, such as Colombo et al. (2019) and Giotopoulos et al. (2017), use the term ICT skills, the term employee digital skills can also be found in the literature. Hence, we will use both terms as synonyms.

This is important, as a significant portion of contemporary literature observes organisational ICT implementation through certain digital skills. Colombo et al. (2019) investigated different types of employees' digital skills (information brokerage, basic, applied/management and technical ICT skills) and their influence on digital automation of business processes. Similarly, organisational ICT use was also found to be denoted by digital skills and competences of employees in the context of national ICT use (Yunis et al., 2012). In this sense, relevant indicators can be related to the number of staff trained for handling ICTs (Cuevas-Vargas et al., 2016), the percentage of personnel with ICT skills (Giotopoulos et al., 2017) or work-related use of ICTs after hours (Lee et al., 2021).

On the other hand, one of the fundamental characteristics of overall organisational ICT implementation is the level of usage of different digital technologies in business conduct (Karimikia, Singh and Joseph, 2020). Cloud computing, as one of the most complex ICTs (Becker et al., 2018), represents a web-based solution for depositing and disseminating data (Vasiljeva et al., 2017) provided by an external service provider, often on a pay-per-use basis (Raut et al., 2018). The main business use of this technology is internal information organisation and management (Ho et al., 2017). Reliance on cloud technology to supplement internally managed non value-crating business activities and processes (Chen \& Tseng, 2013) is oftentimes closely linked to the concept of organisational agility (Liu et al., 2018). Introduction of cloud computing into an organisation can be achieved through three operational modes: software as a service, platform as a service and infrastructure as a service (Grilo \& Jardim-Goncalves, 2011). In recent years, cloud computing has attracted considerable research interest, which varies significantly from an empirical standpoint, but consensually recognises the relation between overall organisational ICT implementation and cloud computing adoption (Raut et al., 2018). 
Competitive, high-paced business environment also requires a business to provide their employees with instant remote access to relevant software (Mwantimwa, 2019), emails, files and documents (Dittes et al., 2019). Devices that allow this kind of remote access are categorised as portable technologies (Wangemann et al., 2003). Nowadays, many businesses are integrating smartphones and similar devices into their business processes and activities (Dittes et al., 2019). Many authors investigated the ways in which remote access to certain ICTs via smartphones improves organisational business performance (Mwantimwa, 2019). Such is the case with lyanda \& Ojo (2008), who observed portable technologies, such as PDAs and laptops, alongside organisational use of software, emails and database servers, in the context of applicability and productivity. Covering the intensity of different ICT components, Becker et al. (2018) focused on portable devices that provided a mobile connection to internet and allowed access to corporate email, relevant business software and databases.

Finally, increased organisational ICT implementation opens up businesses towards more extensive use of available outsourcing options (Kotabe et al., 2008), especially regarding IT assets (Agrawal et al., 2006). Through outsourcing, companies can attain necessary ICT resources and capabilities required for running a successful e-commerce business (Gunasekaran et al., 2002). The summary of the analysed literature, in the context of the two observed dimensions of organisational ICT implementation is shown in Table 1.

Table 1: Analysed ICT implementation literature

\begin{tabular}{|c|c|c|c|}
\hline \multirow[b]{2}{*}{ References } & \multicolumn{2}{|c|}{ Organisational ICT implemetation } & \multirow[b]{2}{*}{$\begin{array}{c}\text { Observed ICT implementation } \\
\text { relation }\end{array}$} \\
\hline & $\begin{array}{c}\text { Human ICT } \\
\text { implementation } \\
\text { aspect }\end{array}$ & $\begin{array}{c}\text { Technological ICT } \\
\text { implemenation aspect }\end{array}$ & \\
\hline $\begin{array}{l}\text { Agrawal et } \\
\text { al., } 2006\end{array}$ & & $\begin{array}{l}\text { Outsourcoing of e-business } \\
\text { projects, relating to their } \\
\text { intent, swiftness and } \\
\text { complexity }\end{array}$ & $\begin{array}{c}\text { Effect of e-business outsourcing } \\
\text { on abnormal positive } \\
\text { organizational returns }\end{array}$ \\
\hline $\begin{array}{l}\text { Becker et al., } \\
2018\end{array}$ & $\begin{array}{c}\text { Significance of } \\
\text { connection to } \\
\text { internet as } \\
\text { subcriterion of ICT } \\
\text { usage }\end{array}$ & $\begin{array}{c}\text { Significance of e-commerce, } \\
\text { e-business and website and } \\
\text { social media usage as } \\
\text { subcriteria of ICT usage }\end{array}$ & $\begin{array}{c}\text { Evaluation and ranking of } \\
\text { national ICT usage in Central } \\
\text { European countires }\end{array}$ \\
\hline $\begin{array}{l}\text { Chen and } \\
\text { Tseng, } 2013\end{array}$ & & $\begin{array}{c}\text { Implementation of cloud } \\
\text { technology in leisure } \\
\text { restaurants }\end{array}$ & $\begin{array}{l}\text { Exploring potential effects of } \\
\text { cloud technology on creating } \\
\text { competitive advantage }\end{array}$ \\
\hline $\begin{array}{l}\text { Colombo et } \\
\text { al., } 2019\end{array}$ & & $\begin{array}{l}\text { Analysis of different kinds of } \\
\text { ICT skills }\end{array}$ & $\begin{array}{l}\text { Evaluating the probability of job } \\
\text { automation, depending on the } \\
\text { employee skillset }\end{array}$ \\
\hline $\begin{array}{l}\text { Cuevas- } \\
\text { Vargas et al., } \\
2016\end{array}$ & & $\begin{array}{l}\text { Use of ICT in different } \\
\text { business processes }\end{array}$ & $\begin{array}{l}\text { Effect of ICT use on improving } \\
\text { business performance }\end{array}$ \\
\hline $\begin{array}{l}\text { Giotopoulos } \\
\text { et al., } 2017\end{array}$ & $\begin{array}{l}\text { Personnel with } \\
\text { ICT skills as a } \\
\text { factor of human } \\
\text { capital }\end{array}$ & $\begin{array}{l}\text { Avaliable ICT resources, such } \\
\text { as information resource } \\
\text { management system, } \\
\text { information systems manager, } \\
\text { computer room and security } \\
\text { back up plan for information } \\
\text { systems }\end{array}$ & $\begin{array}{l}\text { Significance of human capital in } \\
\text { determining the organizational } \\
\text { level of e-sales, interent } \\
\text { integration, ICT infrastructure } \\
\text { and ICT intentions }\end{array}$ \\
\hline $\begin{array}{l}\text { Iyanda and } \\
\text { Ojo, } 2008\end{array}$ & & $\begin{array}{l}\text { ICT use through different } \\
\text { portable technologies and } \\
\text { computer software }\end{array}$ & $\begin{array}{l}\text { Observing the relation between } \\
\text { ICT facilities and ICT adoption }\end{array}$ \\
\hline $\begin{array}{l}\text { Kabongo } \\
\text { and Okpara, } \\
2014\end{array}$ & & $\begin{array}{l}\text { Used and implemented types } \\
\text { of ICTs }\end{array}$ & $\begin{array}{l}\text { The level of ICT adoption by } \\
\text { SMEs }\end{array}$ \\
\hline
\end{tabular}




\begin{tabular}{|c|c|c|c|}
\hline \multirow[b]{2}{*}{ References } & \multicolumn{2}{|c|}{ Organisational ICT implemetation } & \multirow[b]{2}{*}{$\begin{array}{l}\text { Observed ICT implementation } \\
\text { relation }\end{array}$} \\
\hline & $\begin{array}{c}\text { Human ICT } \\
\text { implementation } \\
\text { aspect }\end{array}$ & $\begin{array}{c}\text { Technological ICT } \\
\text { implemenation aspect }\end{array}$ & \\
\hline $\begin{array}{l}\text { Karimikia et } \\
\text { al., } 2020\end{array}$ & & $\begin{array}{l}\text { Overal and specific ICT use } \\
\text { within an organization }\end{array}$ & $\begin{array}{l}\text { The effect of ICT use on job- } \\
\text { related stress, moderated via } \\
\text { job autonomy }\end{array}$ \\
\hline $\begin{array}{c}\text { Kotabe et al., } \\
2008\end{array}$ & & $\begin{array}{l}\text { Approaches to e-commerce } \\
\text { outsourcing }\end{array}$ & $\begin{array}{l}\text { Positive and negative effects of } \\
\text { e-commerce outsourcing in } \\
\text { terms of business performance } \\
\text { and competitiveness }\end{array}$ \\
\hline $\begin{array}{l}\text { Lefophane } \\
\text { and Kalaba, } \\
2021\end{array}$ & & $\begin{array}{l}\text { Differentiating between high } \\
\text { and low ICT intensity } \\
\text { industries based on ICT } \\
\text { intensity index }\end{array}$ & $\begin{array}{l}\text { Effect of ICT intensity on } \\
\text { employee productivity, and } \\
\text { organizational output }\end{array}$ \\
\hline $\begin{array}{l}\text { Lee et al., } \\
2021\end{array}$ & $\begin{array}{l}\text { Specific focus on } \\
\text { work-related use } \\
\text { of ICTs after hours }\end{array}$ & & $\begin{array}{l}\text { Investigating the causal } \\
\text { relationship with employee } \\
\text { fatigue }\end{array}$ \\
\hline $\begin{array}{l}\text { Liu et al., } \\
2018\end{array}$ & & $\begin{array}{l}\text { Cloud infrastructure capability } \\
\text { observed through flexibility } \\
\text { and integration }\end{array}$ & $\begin{array}{l}\text { Effect on organizational agility, } \\
\text { moderated by cloud computing } \\
\text { spending }\end{array}$ \\
\hline $\begin{array}{l}\text { Mwantimwa, } \\
2019\end{array}$ & $\begin{array}{l}\text { Availability of } \\
\text { certain types of } \\
\text { ICT to employees }\end{array}$ & $\begin{array}{c}\text { ICT ownership and frequency } \\
\text { of use }\end{array}$ & $\begin{array}{l}\text { ICT use in different business } \\
\text { processes }\end{array}$ \\
\hline $\begin{array}{l}\text { Ongori and } \\
\text { Migiro, } 2010\end{array}$ & & $\begin{array}{l}\text { Differentiating between } \\
\text { available ICT tools }\end{array}$ & $\begin{array}{c}\text { Analysis of ICT tools in the } \\
\text { context of ICT adoption, along } \\
\text { with barriers, strategies and } \\
\text { outcomes }\end{array}$ \\
\hline $\begin{array}{l}\text { Polder et al., } \\
2018\end{array}$ & & $\begin{array}{c}\text { Analysis of ICT usage intensity } \\
\text { through market share, } \\
\text { efficiency and performance } \\
\text { distribution }\end{array}$ & $\begin{array}{l}\text { Relation between ICT intenisty, } \\
\text { industry-related productivity and } \\
\text { firm dynamism }\end{array}$ \\
\hline $\begin{array}{l}\text { Raut et al., } \\
\quad 2018\end{array}$ & & $\begin{array}{l}\text { Usage of technology as a } \\
\text { factor of influence on cloud } \\
\text { technology adoption }\end{array}$ & $\begin{array}{l}\text { Analysis of cloud computing } \\
\text { adoption and its effect on } \\
\text { business performance }\end{array}$ \\
\hline $\begin{array}{l}\text { Shiels et al., } \\
2003\end{array}$ & & $\begin{array}{l}\text { Exploring ICT adoption } \\
\text { through different business } \\
\text { integration processes }\end{array}$ & $\begin{array}{l}\text { Analyzing the effects of ICT } \\
\text { adoption on SMEs from a multi- } \\
\text { dimensional integration } \\
\text { perspective }\end{array}$ \\
\hline $\begin{array}{l}\text { Yunis et al., } \\
2012\end{array}$ & & $\begin{array}{l}\text { Identifying ICT usage within } \\
\text { the ICT maturity indicator }\end{array}$ & $\begin{array}{l}\text { Exploring the direct and indirect } \\
\text { effects of ICT maturity on global } \\
\text { competitiveness }\end{array}$ \\
\hline
\end{tabular}

On the basis of presented literature, we focus on exploring how organizational ICT implementation affects e-commerce potential of businesses, from both the human and technological perspectives.

\subsection{Reaching e-commerce potential through ICT use}

Businesses with the capacity to undertake organisational adaptations are more likely to yield higher benefits from ICT implementation and invest more in ICT infrastructure. An important part of evaluating the effects of ICT implementation is establishing measurable and controllable links between specific ICT aspects and analysed phenomena (Cuevas-Vargas et al., 2016). 
Organisational implementation intensity of various ICTs influences to a certain extent the Internet integration potential, as well as efficiency and effectiveness of corresponding e-commerce activities (Giotopoulos et al., 2017). Such a deduction is based on the fact that e-commerce, in its essence, represents market-oriented application of different ICTs (Yasin et al., 2014). Also, the use of ICT, the Internet technology in particular, strongly influences corporate e-commerce efforts (Rahayu \& Day, 2017). However, contemporary literature is lacking in terms of investigating the effects of ICT implementation on e-commerce potential, especially in the context of transition economies.

One of the main prerequisites of a successful e-commerce business is a well-developed and functional corporate website (Yavuz \& Welch, 2014), regardless of whether the e-transactions are B2B or B2C in nature (Ongori \& Migiro, 2010). Corporate website functions and characteristics are especially interesting in this context, since they are identified as one of the most important e-commerce success factors (Cullen \& Taylor, 2009). Therefore, an important aspect of e-commerce potential of a B2B or B2C business lies in its capacity to facilitate e-commerce activities through its website. To bridge the gap between ICT implementation and e-commerce potential, the focus of the paper is on examining the relation between organisational ICT implementation and e-commerce website functionality. Special attention is given to businesses operating in transition markets, as digital prowess successfully translated into e-commerce potential provides a basis for evening the ground in terms of competing with businesses from developed markets.

Zaidan (2017), identified the lack of IT skilled employees and infrastructural readiness as being key barriers to organisational internet adoption. Achieving and maintaining a critical mass of "up-to-date" employees in terms of ICT skills and resources has become the pivotal point for many businesses. It is almost impossible to run and maintain a well-functioning e-commerce website without a proper human and infrastructural support. To that end, Ramayah et al. (2016) show that employee internet skills and knowledge are relevant organisational proxies for testing the influence on website continuance intentions. Becker et al. (2018) analysed the number of employees using computers with www. access and portable devices as relevant organisational characteristics, in parallel with the number of enterprises having a website, corporate e-sales and e-procurement activities.

Businesses from developing and transitioning countries with ICT skilled employees are most likely to implement ICT for business purposes in their respective markets (Mwantimwa, 2019). Unfortunately, only few papers specifically analysed businesses from transition economies, although without an empirical angle. In their analysis of strategic value of e-commerce for SMEs from transition markets, Saffu et al. (2008) observed organisational readiness in the context of e-commerce adoption, theoretically implying the link between ICT implementation and e-commerce potential. In the context of ICT use in companies from transition economies, Gerguri-Rashiti et al. (2017) investigated the relation between specific ICT implementation moments, such as Internet connectivity, B2B digital communication and ICT investments, and firm performance, more specifically labour productivity and innovation activities.

The literature review shows that organisational ICT implementation is a success predisposition of a business with e-commerce pretensions. Many B2B and B2C e-businesses rely strongly on well-functioning websites facilitating e-commerce activities. As we have shown that organisational ICT implementation has both human and technological perspective, the proposed conceptual model must take this distinction into account when defining the relations between e-commerce website functionality and ICT implementation. How we approached the model development is shown in the following section.

\section{Conceptual Model and Hypotheses Development}

We have seen that contemporary literature examines the relations between certain employee ICT intensity indicators and specific B2B and B2C website aspects. However, the existing research has not investigated e-commerce website functionality in the wider context of organisational ICT implementation. The main contribution of this paper is the examining of the effect of ICT implementation on businesses' e-commerce potential, from both the human and technological (infrastructural) perspectives. On the basis that the lack of employees with digital skills proved to be a key obstacle to internet adoption within a company (Zaidan, 2017), we formulate our first research hypothesis.

H1: Businesses benefit from higher levels of employee ICT skills in terms of developing e-commerce website functionality. 
Recent research also showed that companies with well-equipped employees skilled in ICT use were more likely to organisationally adopt and integrate newest ICTs (Kabongo \& Okpara, 2014). These predominantly include complex technologies for data capturing, storage, processing, communication, display, integration and collaboration (Ibem \& Laryea, 2014). Organisational implementation of different ICTs has a varying influence on corporate e-commerce development (Yasin et al., 2014) and web technology integration (Giotopoulos et al., 2017). Therefore, in the context of analysing the e-commerce potential of businesses, it is also important to account for potential indirect effects of employee digital intensity on website e-commerce functionality.

Theoretical foundations derived from contemporary literature combine into a conceptual model in which two main dimensions of organisational ICT implementation, employee ICT skills and technological aspect of ICT implementation, are coupled with corporate e-commerce website functionality. One of the fundamental characteristics of overall organisational ICT implementation is the level of usage of different ICTs in business conduct, sometimes referred to as organisational ICT maturity (Yunis et al., 2012). For this reason, modern ICTs were observed in more detail, as potential mediators. In this light, the implementation of latest ICTs, such as cloud computing, portable technologies and digital outsourcing, outlines the overall digital capacity and potential of today's businesses (Yavuz \& Welch, 2014).

Cloud technology can to a certain extent be used to facilitate e-commerce solutions (Grilo \& JardimGoncalves, 2011), especially in conjunction with other technologies (Chen and Tseng, 2013). As an emerging ICT innovation (Liu et al., 2018), cloud technology provides IT infrastructure, such as networks, servers, storage, applications and services, which represent essential supporting elements in creating a modern, well-functioning website (Charif \& Awad, 2016). Therefore, the effect of cloud technology implementation on website e-commerce functionality potential was further investigated in our paper.

\section{H2: Organisational cloud technology usage level influences e-commerce website functionality level.}

In the wake of shifting market paradigm, companies are pressured into making certain organisational adaptations in order to address the requirements of today's digital markets, in which the lack of e-commerce resources represents a significant market obstacle (Yasin et al., 2014). The lack of technical resources, such as the availability of portable technologies (Yasin et al., 2014), represents a significant internal barrier to organisational e-commerce adoption (Kabongo \& Okpara, 2014).

Contemporary research suggests that the efficiency and efficacy of certain e-commerce website features, such as integrated product tracking system, remote accessibility, security and instant availability of relevant information can be improved by organisational implementation of portable technologies (Ilbahar \& Cebi, 2017). Existing studies also propose similar expectations for portable technology implementation in the domain of data and software management (Dittes et al., 2019; Mwantimwa, 2019).

However, research dedicated to empirically investigating the link between organisational portable technology usage and business e-commerce potential is lacking. Building on the existing knowledge, the paper addresses the identified gap by comprehensively investigating the implementation of portable technologies in a wider organisational context, as the mediating factor between labour ICT intensity and corporate website e-commerce potential. Based on this, the following hypothesis is proposed.

\section{H3: Organisational portable technology usage level influences e-commerce website functionality level.}

As more and more companies transition from single to multiple-channel business models, the need for outsourcing certain e-commerce functions becomes more apparent, especially those like website hosting and design, content development and order processing (Pentina \& Hasty, 2009).

Outsourcing of various e-commerce activities is receiving research attention, as an important organisational ICT component which allows businesses to focus on their core competences, whilst maintaining necessary digital market presence (Lee et al., 2003). This implies that the overall level of e-commerce activity externalised by organisations can influence certain internal ICT assets, such as website features, which are closely related to business e-commerce potential (Cullen \& Taylor, 2009). Based on this, the final research hypothesis can be formulated.

\section{H4: Organisational e-commerce outsourcing level influences e-commerce website functionality level.}




\section{Research Design and Methodology}

\subsection{Sample data}

The analysis conducted in this paper is based on the secondary data on the ICT usage in Serbia in 2018, which was kindly provided by the Statistical Office of the Republic of Serbia. The sample is representative in terms of the company size and the level of economic activity for the entire Republic of Serbia. The total sample size was 1,781 companies (response rate was 63.6\%). The surveying was conducted in 2018, during April, via telephone interview. The surveying process, which has been organised annually since 2007 , is conducted according to the methodology and instruments (questionnaire) defined by EUROSTAT. The analysis was conducted on the survey micro-data, provided by SORS.

For the purposes of conducted research, only companies that implemented some form of cloud and portable technologies were analysed. The observed stratum within the total sample numbered 238 companies in total. The structure of the analysed sample is shown in Table 2.

Table 2: Research sample structure

\begin{tabular}{|c|c|}
\hline Sample properties (238 companies) & Frequency \\
\hline \multicolumn{2}{|l|}{ r r r } \\
\hline Small & $74(31.09 \%)$ \\
\hline Medium & $85(35.71 \%)$ \\
\hline Large & $79(33.19 \%)$ \\
\hline \multicolumn{2}{|l|}{ Number of employees } \\
\hline from 10 to 50 & $76(31.93 \%)$ \\
\hline from 51 to 100 & $38(15.97 \%)$ \\
\hline from 101 to 250 & $45(18.91 \%)$ \\
\hline 251 or more & $79(33.19 \%)$ \\
\hline \multicolumn{2}{|l|}{ Industry } \\
\hline Manufacturing & $81(34.03 \%)$ \\
\hline $\begin{array}{l}\text { Electricity, gas, steam and air conditioning supply; water supply, } \\
\text { sewerage }\end{array}$ & $9(3.78 \%)$ \\
\hline Construction & $14(5.88 \%)$ \\
\hline Wholesale and retail & $35(14.71 \%)$ \\
\hline Transportation and storage & $9(3.78 \%)$ \\
\hline Accommodation and food service activities & $12(5.04 \%)$ \\
\hline Information and communication & $44(18.49 \%)$ \\
\hline Real estate; professional, scientific and technical activities & $15(6.30 \%)$ \\
\hline Administrative and support service activities; repair of computers & 19 (7.98\%) \\
\hline
\end{tabular}

Findings from papers on similar or related topics are based on similarly-sized samples. Liu et al. (2018) observed 183 companies in total, whereas Ramayah et al. (2016) conducted their research on 108 businesses. The minimum sample size depends on the type and complexity of the developed statistical model. In this paper, a structural equation model with 5 constructs was used. Item extraction communalities are expected to be .6 or higher. Derived data modelling results provided the minimum value of extraction communalities of .655. For structural equation models with that statistical trait, the minimum sample size of 100 is characteristic (Hair et al., 2018). Thus, the analysed sample of 238 companies is both theoretically and thematically acceptable.

\subsection{Measurement of variables}

Drawing upon previously analysed literature, employee ICT (digital) skills were chosen as the main explanatory variable in the research model. It was conceptualised as a formative latent variable comprised of items depicting the share of employees using computers for business purposes, share of employees using portable devices that allow internet connection via mobile network for business purposes (Becker et al., 2018) and share of employees using internet for business purposes (Shiels et al., 2003).

Confirmatory factor analysis (CFA) was used to create the latent variable (Brown, 2015). Assumptions, such as multivariate normality and the absence of multivariate extreme values, were verified prior to the application of CFA (Harrington, 2008). Reliability was tested using Cronbach's $\alpha$, with the threshold value being .7 
(Kim et al., 2015). Convergent validity was evaluated using construct reliability (CR) and average variance extracted (AVE), with acceptable values being higher than .7 and .5, respectively. Since all indicator values were higher than accepted thresholds and all item loadings being higher than .6 (Loukis et al., 2013), a strong internal consistency was concluded (Fornell and Larcker, 1981). Measurement validation statistics for employee digital skills construct are shown in Table 3.

Table 3: Measurement validation statistics for employee ICT skills construct

\begin{tabular}{|l|c|c|c|c|c|}
\hline \multicolumn{1}{|c|}{ Items } & $\begin{array}{c}\text { Measure } \\
\text { type }\end{array}$ & $\begin{array}{c}\text { Factor } \\
\text { loadings }\end{array}$ & Cronbach's $\alpha$ & CR & AVE \\
\hline $\begin{array}{l}\text { \% of employees who use computers } \\
\text { for business purposes }\end{array}$ & Integer & .942 & & \\
$\begin{array}{l}\text { \% of employees who use portable } \\
\text { devices that allow internet connection } \\
\text { via mobile network for business } \\
\text { purposes } \\
\text { \% of employees who use internet for } \\
\text { business purposes }\end{array}$ & Integer & .642 & .888 & .902 & .760 \\
\hline
\end{tabular}

Since the main predisposition of a successful e-commerce business is a well-designed and functional website (Hernandez et al., 2009), the potential of corporate websites to facilitate e-commerce activities was chosen as the dependent variable in the proposed model. Following this line of reasoning, e-commerce website functionality level was used as a proxy variable and was estimated by the number of present websites features essential for successful e-commerce conduct. Informational capacity, personalisation, customisation, online order processing, tracking capabilities, and linkage with corporate social media profiles were observed as relevant website e-commerce functions (Table 4).

Table 4: Properties of e-commerce website functionality aggregate construct

\begin{tabular}{|l|c|c|}
\hline \multicolumn{1}{|c|}{ Items } & \multicolumn{1}{c|}{ References } & $\begin{array}{c}\text { Measure } \\
\text { type }\end{array}$ \\
\hline $\begin{array}{l}\text { Price list and a } \\
\text { description of goods / } \\
\text { services }\end{array}$ & $\begin{array}{r}\text { Chakraborty et al., 2002; X. Chen et al., 2017; Chiou et al., } \\
\text { 2010; Diaz and Koutra, 2013; Hung, 2017; Lee and Wu, } \\
\text { 2011; Nilashi et al., 2016; Salavati and Hashim, 2015; Wang } \\
\text { et al., 2015; Zhu et al., 2009 }\end{array}$ & Binary \\
\hline $\begin{array}{l}\text { Online ordering / } \\
\text { reservation / booking }\end{array}$ & $\begin{array}{r}\text { Chiou et al., 2010; Diaz and Koutra, 2013; Hung, 2017; Kirk } \\
\text { et al., 2016; Lee and Wu, 2011; Salavati and Hashim, 2015; } \\
\text { Wang et al., 2015; Zhu et al., 2009 }\end{array}$ & Binary \\
\hline $\begin{array}{l}\text { Product/service } \\
\text { customisation options }\end{array}$ & $\begin{array}{r}\text { Chakraborty et al., 2002; Chiou et al., 2010; Zhu et al., 2009 } \\
\text { Order tracking }\end{array}$ & Binary \\
\hline $\begin{array}{l}\text { Personalisation of } \\
\text { website content }\end{array}$ & $\begin{array}{r}\text { Chakraborty et al., 2002; X. Chen et al., 2017; Chiou et al., } \\
\text { 2010; Kirk et al., 2016; Nilashi et al., 2016; Salavati and } \\
\text { Hashim, 2015 }\end{array}$ & Binary \\
\hline $\begin{array}{l}\text { Links to corporate } \\
\text { social media profiles }\end{array}$ & $\begin{array}{r}\text { Chiou et al., 2010; Diaz and Koutra, 2013; Hung, 2017; Kirk } \\
\text { et al., 2016 }\end{array}$ & Binary \\
\hline
\end{tabular}

Contemporary literature also suggests the existence of certain indirect effects of employee digital skills on corporate e-commerce website functionality. These effects are underlined by the fact that organisational willingness to adopt new ICTs increases with more ICT adept employees (Giotopoulos et al., 2017). These indirect effects were evaluated through mediators representing the usage level of cloud computing, portable technologies and e-commerce outsourcing. Recent years have seen ample research on the topic of different uses of cloud and portable technologies. Consequently, these two mediating variables were introduced into the model as the number of different types of cloud computing (Table 5) and portable technologies (Table 6) employed by an organisation. 
Table 5: Properties of cloud technology usage level aggregate construct

\begin{tabular}{|l|c|c|}
\hline \multicolumn{1}{|c|}{ Items } & References & Measure type \\
\hline Email services & Vasiljeva et al., 2017 & Binary \\
\hline Hosting databases & $\begin{array}{r}\text { Charif and Awad, 2016; Chen and Tseng, 2013; } \\
\text { Vasiljeva et al., 2017 }\end{array}$ & Binary \\
\hline File storage & $\begin{array}{r}\text { Charif and Awad, 2016; Chen and Tseng, 2013; Liu } \\
\text { et al., 2018; Vasiljeva et al., 2017 }\end{array}$ & Binary \\
\hline $\begin{array}{l}\text { Office software } \\
\text { Financial/accounting } \\
\text { software }\end{array}$ & $\begin{array}{r}\text { Charif and Awad, 2016; Chen and Tseng, 2013; Liu } \\
\text { et al., 2018; Vasiljeva et al., 2017 }\end{array}$ & Binary \\
\hline CRM software & $\begin{array}{r}\text { Charif and Awad, 2016; Chen and Tseng, 2013; Liu } \\
\text { et al } \text { al., 2018; Vasiljeva et al., 2017 }\end{array}$ & Binary \\
\hline Computing power & Liu et al., 2018; Vasiljeva et al., 2017 & Binary \\
\hline
\end{tabular}

Table 6: Properties of portable technology usage level aggregate construct

\begin{tabular}{|l|c|c|}
\hline \multicolumn{1}{|c|}{ Items } & \multicolumn{1}{|c|}{ References } & Measure type \\
\hline Use for email access & Aguilera et al., 2012; lyanda and Ojo, 2008 & Binary \\
\hline $\begin{array}{l}\text { Use for access and } \\
\text { modification of corporate } \\
\text { documents }\end{array}$ & Aguilera et al., 2012; lyanda and Ojo, 2008 & Binary \\
\hline $\begin{array}{l}\text { Use for accessing } \\
\text { business software }\end{array}$ & Chen and Tseng, 2013; lyanda and Ojo, 2008 & Binary \\
\hline
\end{tabular}

Outsourcing digital activities and processes represents a common market occurrence and an increasingly viable option for many businesses trying to develop and optimise their e-commerce activities (Agrawal et al., 2006). This is especially true for companies with employees skilled in ICT use, which tend to see outsourcing as an opportunity to acquire important digital resources, otherwise unattainable using internal means (Kotabe et al., 2008). In the narrow research context, the overall level of e-commerce externalisation depends on the scope and share of e-commerce activities being outsourced (Kedia \& Mukherjee, 2009). On this basis, the effect of e-commerce outsourcing level was modelled using a 4-point nominal scale (Table 7).

Table 7: Organisational e-commerce outsourcing level

\begin{tabular}{|c|c|}
\hline Scale & Explanation \\
\hline 0 & Organisation does not sell its products or services electronically \\
\hline 1 & Organisation sells its products and services using external e-channels \\
\hline 2 & $\begin{array}{l}\text { Organisation sells its products and services using internal, company-owned } \\
\text { e-channels }\end{array}$ \\
\hline 3 & $\begin{array}{l}\text { Organisation sells its products and services using both internal and external } \\
\text { e-channels }\end{array}$ \\
\hline
\end{tabular}

Items from the survey questionnaire, which constituted the observed model variables, do not represent the preferences or perceptions of the respondents, but mostly binary answers to specific technical questions. This reduces the potential for the occurrence of common method bias. However, as the single response per company provided answers to both independent and dependent items, the occurrence of common method bias in this context is possible. Therefore, we employed Harman's single factor test to examine the possibility of common method bias occurrence (Tehseen et al., 2017). The conducted analysis showed that the highest covariance explained from a single component was $15.2 \%$, which is less than half of the variance, indicating that common method bias is not present in this research (Jakobsen \& Jensen, 2015). 


\section{Results}

The research model analysed certain mediation effects, which is why model estimation was performed using covariance-based structural equation modelling (SEM) (Hair et al., 2014). All calculations were made using AMOS 23 software. The maximum likelihood method was used to estimate unknown parameters, since preconditions for using this method, such as multivariate normality and the absence of multivariate extremal values, were met (Byrne, 2013).

In SEM, evaluating the validity of the proposed model includes testing several types of indices. The initial mandatory step in basic goodness-of-fit reporting implies calculating the chi-square statistic, along with associated degrees of freedom and p-value. No clear scientific consensus exists on which indices should be analysed when reporting model fit in SEM. The main body of literature distinguishes between absolute fit indices and relative fit indices, sometimes also referred to as incremental fit indices (Hooper et al., 2008). Reporting absolute fit indices usually includes goodness of fit index (GFI), adjusted goodness of fit index (AGFI), root mean square error of approximation (RMSEA) and standardized root mean residual (SRMR) (Bollen \& Long, 1993). Relative fit indices encompass comparative fit index (CFI), Tucker Lewis index (TLI), normed fit index (NFI) and incremental fit index (IFI) (Hair et al., 2014).

In terms of relative model fit, NFI, TLI, CFI and IFI indicator values are all higher than .95, indicating acceptable fit to the data (Schreiber et al., 2006). For absolute model fit values, both GFI and AGFI are higher than .95, SRMR is lower than 0.08 and RMSEA is lower than 0.03 , indicating excellent model fit (Hooper et al., 2008). Calculated model fit measurements are shown in Table 8.

Table 8: Model fit measurements for the proposed research model

\begin{tabular}{|c|c|c|c|c|c|c|c|c|c|c|}
\hline Chi-square & DF & p-value & NFI & IFI & TLI & CFI & GFI & AGFI & SRMR & RMSEA \\
\hline 12.995 & 11 & .294 & .981 & .997 & .994 & .997 & .984 & .960 & .043 & .028 \\
\hline
\end{tabular}

Since general model fit parameters have been satisfied, subsequent model calculations were performed. The modelling approach used is similar to those implemented by Andreu et al. (2010) and Yunis et al. (2012). Summarised model findings are shown in Figure 1.

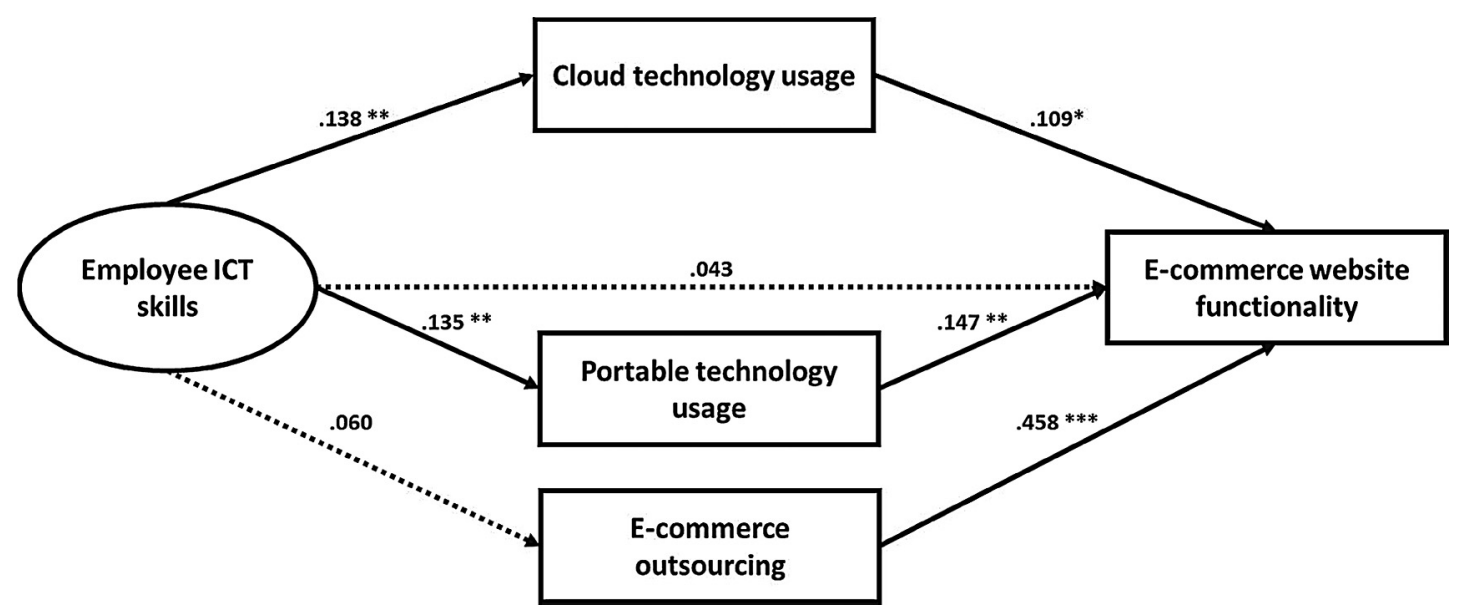

Figure 1. Statistical model with standardised regression weights, significant at *.1, **.05 and $* * * .01$ levels (Haas et al., 2004)

Findings show that employee digital skills have no direct effect on e-commerce website functionality level of businesses. This led to the rejection of $\mathrm{H} 1$. In terms of indirect effect of employee ICT skills, the analysis confirmed that cloud and portable technologies represent important ICT components for translating employee ICT intensity into website e-commerce potential. This confirmed $\mathrm{H} 2$ and $\mathrm{H} 3$. In terms of e-commerce outsourcing, its direct effect on e-commerce website functionality has been identified both as the strongest and most significant one. However, the relation between employee ICT skills and e-commerce outsourcing level has not been confirmed, which ultimately led to the rejection of $\mathrm{H} 4$. 
As an additional proofing step, the analysis of hypothesised mediatory effects of observed ICT components was performed using the approach proposed by Baron and Kenny (1986) with bootstrapping technique (Shrout \& Bolger, 2002). For this calculation 5000 bootstrap samples with bias-corrected confidence intervals were used. The results confirmed the aforementioned conclusions entirely (Table 9).

Table 9: Results of indirect effect testing using Baron-Kenny approach

\begin{tabular}{|l|c|c|c|}
\hline \multicolumn{1}{|c|}{ Relationship } & $\begin{array}{c}\text { Direct effect } \\
\text { without Mediator } \\
\text { (sig.) }\end{array}$ & $\begin{array}{c}\text { Direct effect } \\
\text { with Mediator } \\
\text { (sig.) }\end{array}$ & $\begin{array}{c}\text { Standardised } \\
\text { indirect effect } \\
\text { significance } \\
\text { (sig.) }\end{array}$ \\
\hline $\begin{array}{l}\text { Employee ICT skills } \rightarrow \text { Cloud } \\
\text { technology usage level } \rightarrow \text { E- } \\
\text { commerce website e-commerce } \\
\text { functionality level }\end{array}$ & $.103(.117)$ & $.080(.202)$ & $.023^{\star *}(.022)$ \\
\hline $\begin{array}{l}\text { Employee ICT skills } \rightarrow \text { Portable } \\
\text { technology usage level } \rightarrow \text { E- } \\
\text { commerce website functionality level }\end{array}$ & $.103(.117)$ & $.079(.220)$ & $.025^{\star *}(.048)$ \\
\hline $\begin{array}{l}\text { Employee ICT skills } \rightarrow \text { E-commerce } \\
\text { outsourcing level } \rightarrow \text { E-commerce } \\
\text { website functionality level }\end{array}$ & $.103(.117)$ & $.076(.192)$ & $.027(.380)$ \\
\hline
\end{tabular}

Note: significant at *.1, **.05 and ***.01 levels (Haas et al., 2004)

The standardised indirect (mediated) effect of labour ICT intensity, via cloud technology usage level, on ecommerce website functionality level is .023 and is significantly different from zero at ${ }^{* *} .05$ level ( $p$-value of .022). This implies that when employee ICT skills increase by a standard deviation, the e-commerce website functionality level consequently increases by .023 standard deviations. Additionally, a mediated effect of employee digital skills, via portable technology usage level, on e-commerce website functionality level is .025 and is significantly different from zero at ${ }^{* *} .05$ level ( $p$-value of .048). This effect causes an increase in e-commerce website functionality level by .025 standard deviations upon a positive change of a single unit of standard deviation in employee ICT skills. These two combined effects amount to the total standardised indirect model effect of ${ }^{* \star} .062$.

As the large portion of contemporary literature focuses specifically on examining SMEs in the context of ICT implementation (Shiels et al., 2003; Ongori \& Migiro, 2010; Kabongo \& Okpara, 2014; Ramayah et al., 2016; Giotopoulos et al., 2017; Vasiljeva et al., 2017), the analysis was consequently expanded so as to include business size differentiation. For this, the critical ratio analyses regarding differences between path coefficients of small, medium and large enterprises were performed (Ho, 2014). The results are shown in Table 10.

Table 10: Pairwise comparison of critical ratios for differences between analysed path coefficients, in terms of company size

\begin{tabular}{|l|c|c|c|}
\hline \multicolumn{1}{|c|}{ Path } & Small/Medium & Medium/Large & Small/Large \\
\hline $\begin{array}{l}\text { Labour ICT intensity } \rightarrow \text { Cloud } \\
\text { technology usage level }\end{array}$ & -.386 & .964 & .465 \\
\hline $\begin{array}{l}\text { Cloud technology usage level } \rightarrow \\
\text { Website functionality level }\end{array}$ & 1.542 & $\mathbf{- 2 . 0 7 5 ^ { \star * }}$ & -.461 \\
\hline $\begin{array}{l}\text { Labour ICT intensity } \rightarrow \text { Portable } \\
\text { technology usage level }\end{array}$ & 1.066 & .358 & 1.326 \\
\hline $\begin{array}{l}\text { Portable technology usage level } \rightarrow \\
\text { Website functionality level }\end{array}$ & 1.468 & .393 & $\mathbf{1 . 8 1 2 ^ { * }}$ \\
\hline $\begin{array}{l}\text { E-commerce outsourcing level } \rightarrow \\
\text { Website functionality level }\end{array}$ & .179 & -1.371 & -1.039 \\
\hline
\end{tabular}

The comparison value of -2.075 represents the difference between the estimate of path coefficient of cloud technology usage level and website functionality level (for large enterprises) and the same estimate of path coefficient for medium enterprises, divided by an estimate of standard error of the difference. We can con- 
clude that this parameter is statistically significant at the **.05 level $(< \pm 1.96, p<.05)$. Correct modelling approach implies, under suitable assumptions, that this critical ratio or z-statistic has a standard normal distribution.

The analysis also indicated that one of the pairwise comparisons between path coefficients of portable technology usage level is significant $(< \pm 1.645, p<.1)$. The value of 1.812 represent the difference between the estimate of path coefficient of large enterprises and the same estimate of path coefficient for small businesses, divided by an estimate of the standard error of the difference. The presented findings were further confirmed via path coefficient difference test at the *.1 level.

\section{Discussion}

In the discussion part, we elaborate on theoretical and managerial implications of the derived results. As the empirical findings were based on a sample from the Serbian market, certain comments regarding transition economies will be provided, as a starting point for future research and discussions.

The conducted research shows that no significant direct relationship between employee ICT skills and ecommerce website functionality level exists. Similar findings were reported by Ramayah et al. (2016), where employee IS knowledge showed no influence on website continuance intentions in Malesyia, and Nurmilaakso (2009), who identified no link between website and labour productivity in European businesses. An additional comment based on the analysed sample could be that businesses operating in transition markets follow the similar pattern regarding organisational ICT implementation as their counterparts from developed markets, in the context of developing e-commerce potential. For companies operating in transition economies, equipping and training employees for ICT use is vital in keeping up with the digital pace of modern markets. This does not have direct repercussions on corporate website capacity to facilitate e-commerce, but it does provide a basis for utilising organisational ICT components to develop e-commerce potential.

The findings suggest that businesses with good ICT infrastructure access and adequate employee ICT knowledge are more likely to utilise the potential of cloud computing for optimising activities, such as networking, data storing and software usage (Charif \& Awad, 2016). This positively influences organisational implementation of website features aimed at enabling e-commerce, such as online ordering, tracking, personalisation and customisation, especially in the early stages of e-business development (Cullen \& Taylor, 2009). This conclusion is in contrast with that of Raut et al. (2018), who found a negative relation between the usage of technology and cloud computing adoption in India. This can be attributed to the fact that small transition economies provide more potential for implementing relatively standardised cloud-based solutions, rather than developing specific, internal solutions, which are more adapted to local requirements of large developing economies, such as India.

The presented results also show that the organisational implementation of portable technologies helps develop e-commerce website functionality, especially when coupled with a high level of employee ICT skills. This implies that intensive use of portable devices in everyday business activities enables employees to increase the overall responsiveness related to providing actual, real time data on the corporate website, which is essential for efficient functioning of services, such as online ordering, shipment tracking and communication with website visitors (Ilbahar \& Cebi, 2017).

The strongest link identified in the developed model was between the e-commerce outsourcing level and the e-commerce website functionality level. With the externalisation of certain e-commerce activities, the e-commerce website functionality level consequently increases, due to improvements of existing website services and the acquisition of the new ones (Gunasekaran et al., 2002). On the contrary, the e-commerce outsourcing level does not appear to be a significant mediator in the proposed model, as the data show no link with the employee ICT skills. In terms of organising e-commerce activities, no single best solution exists. Companies focused on physical sales can benefit from externalising e-sales, but the same can be true for certain ICT-intensive businesses with other core competences aside from sales, such as product innovativeness or technological prowess. Businesses from transition economies can reap significant benefits when utilising well-established digital solutions through outsourcing.

The presented findings also possess certain managerial implications. As shown previously, employee ICT skills are more important in the indirect context, rather than the direct one, especially in terms of defining website e-commerce potential. This implies that it is not so important to possess ICTs as to possess the right kind 
of ICT, and being able to implement it in the right way. Research findings indicated two interesting differences in organisational ICT implementation, depending on the size of the company.

Cloud technology has proven to be very important for medium-sized enterprises when it comes to developing e-commerce website functionality, especially in comparison with large enterprises. This implies that medium-sized businesses benefit from focusing their human resources on developing core competences, while implementing internet-based solutions, primarily for non-value adding activities. On the contrary, large companies possess the resource pool, which enables them to tackle the majority of business activities internally, thus increasing controllability and adjustability.

In terms of investing in portable technologies, large companies have been shown to benefit the most from enabling their employees instant and customised access to relevant data, coupled with increasing process controllability. In comparison, small businesses lack resources and economy of scale to reap significant benefits in terms of e-commerce website functionality development, and should thus focus their employee engagement on attaining available digital pre-made online solutions.

\section{Conclusion and Limitations}

The capacity of employees to use different ICTs, referred to in this paper as employee ICT (digital) skills, represents a precondition in achieving competitiveness in the eyes of digitally advanced customers. E-commerce, although still a developing process, is already considered a must-have marketing channel, even for businesses operating in transition markets (Saffu et al., 2008). As such, it is highly dependent on the quality of always-improving websites and their e-commerce capabilities (Berman \& Thelen, 2018). In order to contribute to the existing literature, both direct and indirect effects of employee ICT skills on website capacity to facilitate e-commerce activities were examined.

The assumption that employee ICT proficiency is a standalone factor influencing the capacity of website to support ecommerce activities is not supported by presented findings. Results show that businesses need an integrated, synergetic approach which utilises other digital resources, besides ICT seeking work environment, to develop a well-functioning website with e-commerce capabilities.

The paper theoretically expands contemporary literature as cloud computing has been confirmed as a significant ICT mediating the effect of employee digital skills on website e-commerce potential. This contrasts findings by Raut et al. (2018), who identified a negative relation between the usage of technology and the cloud computing adoption. This finding can represent an interesting starting point for future research, as it implies that certain differences between companies from transition markets and those from developing countries exist in terms of cloud computing usage. Additionally, the use of portable technologies was also identified as a significant mediator. High levels of employee ICT skills showed to be a key precondition for successful organisational adoption of portable technologies and their implementation in advancing ecommerce capabilities of corporate websites.

Relevant managerial implications are closely related to differentiating organisational ICT implementation regarding the size of the business. Medium-sized businesses have been identified as most proficient in utilising cloud computing in the context of e-commerce potential creation, especially in comparison with their larger counterparts. On the other hand, large enterprises draw most of the website e-commerce potential from investing in portable technologies, especially when compared to small businesses with limited resources. These findings provide a unique insight into which ICTs are the most important, depending on the phase of business development. E-business managers should focus limited organizational resources upon adopting and implementing ICTs with the highest yield in terms of e-commerce returns.

This study has certain limitations that are worth mentioning. The research model was based on the stratum of observed companies from Serbia, which is recognized as a representative transition economy (Kapoulas \& Ratkovic, 2015). Although presented findings are unambiguous and internationally applicable, national specificities should still be mentioned. The potential for conclusions generalisation is mainly limited to countries undergoing transition. Finally, the number of modelled factors was limited to a couple of specific ICTs. Further research into other organisational ICT components is needed, especially regarding e-commerce outsourcing approaches.

\section{Acknowledgments}

The authors would like to thank the Statistical Office of the Republic of Serbia for providing the dataset used in this research. 


\section{REFERENCES}

[1] Agrawal, M., Kishore, R., \& Rao, H. R. (2006). Market reactions to E-business outsourcing announcements: An event study. Information \& Management, 43(7), 861-873. DOI: 10.1016/j.im.2006.08.002

[2] Aguilera, A., Guillot, C., \& Rallet, A. (2012). Mobile ICTs and physical mobility: Review and research agenda. Transportation Research Part A: Policy and Practice, 46(4), 664-672. DOI:10.1016/j.tra.2012.01.005

[3] Andreu, L., Aldas, J., Enrique Bigne, J., \& Mattila, A. S. (2010). An analysis of e-business adoption and its impact on relational quality in travel agency-supplier relationships. Tourism Management, 31(6), $777-$ 787. DOI:10.1016/j.tourman.2009.08.004

[4] Baron, R. M., \& Kenny, D. A. (1986). The moderator-mediator variable distinction in social psychological research: Conceptual, strategic, and statistical considerations. Journal of Personality and Social Psychology, 51(6), 1173.

[5] Becker, J., Becker, A., Sulikowski, P., \& Zdziebko, T. (2018). ANP-based analysis of ICT usage in Central European enterprises. Procedia Computer Science, 126, 2173-2183. DOI:10.1016/j.procs.2018.07.231

[6] Berman, B., \& Thelen, S. (2018). Planning and implementing an effective omnichannel marketing program. International Journal of Retail \& Distribution Management, 46(7), 598-614. DOI:10.1108/IJRDM-08-2016-0131

[7] Bollen, K. A., \& Long, S. J. (1993). Testing Structural Equation Models (1 edition). SAGE Publications, Inc.

[8] Brown, T. A. (2015). Confirmatory Factor Analysis for Applied Research, Second Edition. Guilford Publications.

[9] Byrne, B. M. (2013). Structural Equation Modeling With AMOS: Basic Concepts, Applications, and Programming, Second Edition. Routledge. DOI:10.4324/9780203805534

[10] Chakraborty, G., Lala, V., \& Warren, D. (2002). An empirical investigation of antecedents of B2B Websites' effectiveness. Journal of Interactive Marketing, 16(4), 51-72. DOI:10.1002/dir.10044

[11] Charif, B., \& Awad, A. I. (2016). Towards smooth organisational adoption of cloud computing: A customer-provider security adaptation. Computer Fraud \& Security, 2016(2), 7-15. DOI:10.1016/S13613723(16)30016-1

[12] Chen, L.-C., \& Tseng, C.-Y. (2013). Managing service innovation with cloud technology. Global Business Perspectives, 1(4), 379-390. DOI:10.1007/s40196-013-0027-2

[13] Chen, X., Huang, Q., \& Davison, R. M. (2017). The role of website quality and social capital in building buyers' loyalty. International Journal of Information Management, 37(1), 1563-1574. DOI:10.1016/j.ijinfomgt.2016.07.005

[14] Chiou, W.-C., Lin, C.-C., \& Perng, C. (2010). A strategic framework for website evaluation based on a review of the literature from 1995-2006. Information \& Management, 47(5-6), 282-290. DOI:10.1016/j.im.2010.06.002

[15] Colombo, E., Mercorio, F., \& Mezzanzanica, M. (2019). Al meets labor market: Exploring the link between automation and skills. Information Economics and Policy, 47, 27-37. DOI:10.1016/j.infoecopol.2019.05.003

[16] Cuevas-Vargas, H., Estrada, S., \& Larios-Gómez, E. (2016). The Effects of ICTs As Innovation Facilitators for a Greater Business Performance. Evidence from Mexico. Procedia Computer Science, 91, 47-56. DOI:10.1016/j.procs.2016.07.040

[17] Cullen, A. J., \& Taylor, M. (2009). Critical success factors for B2B e commerce use within the UK NHS pharmaceutical supply chain. International Journal of Operations \& Production Management, 29(11), 1156-1185. DOI:10.1108/01443570911000177

[18] Díaz, E., \& Koutra, C. (2013). Evaluation of the persuasive features of hotel chains websites: A latent class segmentation analysis. International Journal of Hospitality Management, 34, 338-347. DOI:10.1016/j.ijhm.2012.11.009

[19] Dittes, S., Richter, S., Richter, A., \& Smolnik, S. (2019). Toward the workplace of the future: How organizations can facilitate digital work. Business Horizons, 62(5), 649-661. DOI:10.1016/j.bushor.2019.05.004

[20] Fornell, C., \& Larcker, D. F. (1981). Evaluating Structural Equation Models with Unobservable Variables and Measurement Error. Journal of Marketing Research, 18(1), 39-50. JSTOR. DOI:10.2307/3151312

[21] Gërguri-Rashiti, S., Ramadani, V., Abazi-Alili, H., Dana, L.-P., \& Ratten, V. (2017). ICT, Innovation and Firm Performance: The Transition Economies Context: ICT, Innovation and Firm Performance. Thunderbird International Business Review, 59(1), 93-102. DOI:10.1002/tie.21772

[22] Giotopoulos, I., Kontolaimou, A., Korra, E., \& Tsakanikas, A. (2017). What drives ICT adoption by SMEs? Evidence from a large-scale survey in Greece. Journal of Business Research, 81, 60-69. DOI:10.1016/j.jbusres.2017.08.007 
[23] Grilo, A., \& Jardim-Goncalves, R. (2011). Challenging electronic procurement in the AEC sector: A BIMbased integrated perspective. Automation in Construction, 20(2), 107-114. DOI:10.1016/j.autcon.2010.09.008

[24] Gunasekaran, A., Marri, H. B., McGaughey, R. E., \& Nebhwani, M. D. (2002). E-commerce and its impact on operations management. International Journal of Production Economics, 75(1-2), 185-197. DOI:10.1016/S0925-5273(01)00191-8

[25] Haas, R. E., Nugent, K. E., \& Rule, R. A. (2004). The use of discriminant function analysis to predict student success on the NCLEX-RN. The Journal of Nursing Education, 43(10), 440-446.

[26] Hair, J. F., Black, W. C., Babin, B. J., \& Anderson, R. E. (2018). Multivariate Data Analysis, 8th edition. CENGAGE INDIA.

[27] Hair, J. F., Gabriel, M., \& Patel, V. (2014). AMOS Covariance-Based Structural Equation Modeling (CBSEM): Guidelines on Its Application as a Marketing Research Tool. Revista Brasileira de Marketing, 113(2). DOI:10.5585/remark.v13i2.2718

[28] Hanclova, J., Doucek, P., Fischer, J., \& Vitavska, K. (2014). Does ICT capital affect economic growth in the EU-15 and EU-12 countries? Journal of Business Economics and Management, 16(2), 387-406. DOI:10.3846/16111699.2012.754375

[29] Harrington, D. (2008). Confirmatory Factor Analysis. Oxford University Press.

[30] Hernandez, B., Jimenez, J., \& Martin, M. J. (2009). Key website factors in e-business strategy. International Journal of Information Management, 29(5), 362-371. DOI:10.1016/j.ijinfomgt.2008.12.006

[31] Ho, R. (2014). Handbook of Univariate and Multivariate Data Analysis with IBM SPSS (2ed). CRC Press, Taylor \& Francis Group.

[32] Ho, S. M., Ocasio-Velazquez, M., \& Booth, C. (2017). Trust or consequences? Causal effects of perceived risk and subjective norms on cloud technology adoption. Computers \& Security, 70, 581-595. DOI:10.1016/j.cose.2017.08.004

[33] Hooper, D., Coughlan, J., \& Mullen, M. (2008). Structural Equation Modelling: Guidelines for Determining Model Fit. Electronic Journal of Business Research Methods, 6(1), 53-60. DOI:10.21427/D7CF7R

[34] Hung, C.-L. (2017). Online positioning through website service quality: A case of star-rated hotels in Taiwan. Journal of Hospitality and Tourism Management, 31, 181-188. DOI:10.1016/j.jhtm.2016.12.004

[35] Ibarra, D., Ganzarain, J., \& Igartua, J. I. (2018). Business model innovation through Industry 4.0: A review. Procedia Manufacturing, 22, 4-10. DOI:10.1016/j.promfg.2018.03.002

[36] Ibem, E. O., \& Laryea, S. (2014). Survey of digital technologies in procurement of construction projects. Automation in Construction, 46, 11-21. DOI: 10.1016/j.autcon.2014.07.003

[37] Ilbahar, E., \& Cebi, S. (2017). Classification of design parameters for E-commerce websites: A novel fuzzy Kano approach. Telematics and Informatics, 34(8), 1814-1825. DOI:10.1016/j.tele.2017.09.004

[38] Iyanda, O., \& Ojo, S. O. (2008). Motivation, influences, and perceived effect of ICT adoption in Botswana organizations. International Journal of Emerging Markets, 3(3), 311-322. DOI:10.1108/17468800810883710

[39] Jakobsen, M., \& Jensen, R. (2015). Common method bias in public management studies. International Public Management Journal, 18(1), 3-30.

[40] Kabadayi, S. (2008). Adding direct or independent channels to multiple channel mix. Direct Marketing: An International Journal, 2(2), 66-80. DOI:10.1108/17505930810881734

[41] Kabongo, J. D., \& Okpara, J. O. (2014). ICT possession among Congolese SMEs: An exploratory study. Journal of Small Business and Enterprise Development, 21(2), 313-326. DOI:10.1108/JSBED-10-20130143

[42] Kapoulas, A., \& Ratkovic, D. (2015). E-CRM dilemmas in developing markets: The case of a tourism company in Serbia. European Journal of Tourism Research, 9, 24-40.

[43] Karimikia, H., Singh, H., \& Joseph, D. (2020). Negative outcomes of ICT use at work: Meta-analytic evidence and the role of job autonomy. Internet Research, 31(1), 159-190. DOI:10.1108/INTR-09-20190385

[44] Kedia, B. L., \& Mukherjee, D. (2009). Understanding offshoring: A research framework based on disintegration, location and externalization advantages. Journal of World Business, 12.

[45] Kim, M., Suresh, N. C., \& Kocabasoglu-Hillmer, C. (2015). A contextual analysis of the impact of strategic sourcing and E-procurement on performance. Journal of Business \& Industrial Marketing, 30(1), 1-16. DOI:10.1108/JBIM-01-2012-0010

[46] Kirk, K., Ractham, P., \& Abrahams, A. (2016). Website development by nonprofit organizations in an emerging market: A case study of Thai websites. International Journal of Nonprofit and Voluntary Sector Marketing, 21(3), 195-211. DOI:10.1002/nvsm.1557

[47] Kotabe, M., Mol, M. J., \& Murray, J. Y. (2008). Outsourcing, performance, and the role of e-commerce: A dynamic perspective. Industrial Marketing Management, 37(1), 37-45. DOI:10.1016/j.indmarman.2007.06.011 
[48] Lee, F.-H., \& Wu, W.-Y. (2011). Moderating effects of technology acceptance perspectives on e-service quality formation: Evidence from airline websites in Taiwan. Expert Systems with Applications, 38(6), 7766-7773. DOI:10.1016/j.eswa.2010.12.131

[49] Lee, J.-N., Huynh, M. Q., Kwok, R. C.-W., \& Pi, S.-M. (2003). IT Outsourcing E Past, Present, and. Communications of the ACM, 46(5), 6. DOI:10.1.1.468.2394

[50] Lee, S., Zhou, Z. E., Xie, J., \& Guo, H. (2021). Work-related use of information and communication technologies after hours and employee fatigue: The exacerbating effect of affective commitment. Journal of Managerial Psychology, 36(6), 477-490. DOI:10.1108/JMP-12-2019-0677

[51] Lefophane, M. H., \& Kalaba, M. (2021). Estimating effects of ICT intensity on productivity, employment and output in South Africa: An industry-level analysis. Information Technology for Development, 0(0), 1-26. DOI:10.1080/02681102.2021.1882367

[52] Li, J., Hallsworth, A. G., \& Coca Stefaniak, J. A. (2020). Changing Grocery Shopping Behaviours Among Chinese Consumers At The Outset Of The COVID-19 Outbreak. Tijdschrift Voor Economische En Sociale Geografie, 111(3), 574-583. DOI:10.1111/tesg.12420

[53] Liu, S., Chan, F. T. S., Yang, J., \& Niu, B. (2018). Understanding the effect of cloud computing on organizational agility: An empirical examination. International Journal of Information Management, 43, 98-111. DOI:10.1016/j.jinfomgt.2018.07.010

[54] Loukis, E., Soto-Acosta, P., \& Pazalos, K. (2013). Using structural equation modelling for investigating the impact of e-business on ICT and non-ICT assets, processes and business performance. Operational Research, 13(1), 89-111. DOI:10.1007/s12351-011-0110-x

[55] Mwantimwa, K. (2019). ICT usage to enhance firms' business processes in Tanzania. Journal of Global Entrepreneurship Research, 9(1), 46. DOI:10.1186/s40497-019-0170-6

[56] Nilashi, M., Jannach, D., Ibrahim, O. bin, Esfahani, M. D., \& Ahmadi, H. (2016). Recommendation quality, transparency, and website quality for trust-building in recommendation agents. Electronic Commerce Research and Applications, 19, 70-84. DOI:10.1016/j.elerap.2016.09.003

[57] Nowinski, W., \& Rialp, A. (2013). Drivers and strategies of international new ventures from a Central European transition economy. Journal of East European Management Studies, 18(2), 191-231. DOI:10.5771/0949-6181-2013-2-191

[58] Nurmilaakso, J.-M. (2009). ICT solutions and labor productivity: Evidence from firm-level data. Electronic Commerce Research, 9(3), 173-181. DOI:10.1007/s10660-009-9034-4

[59] Ongori, H., \& Migiro, S. O. (2010). Information and communication technologies adoption in SMEs: Literature review. Journal of Chinese Entrepreneurship, 2(1), 93-104. DOI:10.1108/17561391011019041

[60] Pentina, I., \& Hasty, R. W. (2009). Effects of Multichannel Coordination and E-Commerce Outsourcing on Online Retail Performance. Journal of Marketing Channels, 16(4), 359-374. DOI:10.1080/10466690903188021

[61] Picot-Coupey, K., Hure, E., \& Piveteau, L. (2016). Channel design to enrich customers' shopping experiences: Synchronizing clicks with bricks in an omni-channel perspective - the Direct Optic case. International Journal of Retail \& Distribution Management, 44(3), 336-368. DOI:10.1108/IJRDM-04-20150056

[62] Polder, M., de Bondt, H., \& van Leeuwen, G. (2018). Business dynamics, industry productivity growth, and the distribution of firm-level performance: Evidence for the role of ICT using Dutch firm-level data. The Journal of Technology Transfer, 43(6), 1522-1541. DOI:10.1007/s10961-016-9549-5

[63] Rahayu, R., \& Day, J. (2017). E-commerce adoption by SMEs in developing countries: Evidence from Indonesia. Eurasian Business Review, 7(1), 25-41. DOI:10.1007/s40821-016-0044-6

[64] Ramayah, T., Ling, N. S., Taghizadeh, S. K., \& Rahman, S. A. (2016). Factors influencing SMEs website continuance intention in Malaysia. Telematics and Informatics, 33(1), 150-164. DOI:10.1016/j.tele.2015.06.007

[65] Raut, R. D., Priyadarshinee, P., Gardas, B. B., \& Jha, M. K. (2018). Analyzing the factors influencing cloud computing adoption using three stage hybrid SEM-ANN-ISM (SEANIS) approach. Technological Forecasting and Social Change, 134, 98-123. DOI:10.1016/j.techfore.2018.05.020

[66] Saffu, K., Walker, J. H., \& Hinson, R. (2008). Strategic value and electronic commerce adoption among small and medium sized enterprises in a transitional economy. Journal of Business \& Industrial Marketing, 23(6), 395-404. DOI:10.1108/08858620810894445

[67] Salavati, S., \& Hashim, N. H. (2015). Website adoption and performance by Iranian hotels. Tourism Management, 46, 367-374. DOI:10.1016/j.tourman.2014.07.017

[68] Salciuviene, L., Reardon, J., \& Auruskeviciene, V. (2011). Antecedents of performance of multi level channels in transitional economies. Baltic Journal of Management, 6(1), 89-104. DOI:10.1108/17465261111100914

[69] Schreiber, J. B., Stage, F. K., \& King, J. (2006). Reporting Structural Equation Modeling and Confirmatory Factor Analysis Results: A Review. The Journal of Educational Research, 99(6), 15. 
[70] Shiels, H., Mclvor, R., \& O'Reilly, D. (2003). Understanding the implications of ICT adoption: Insights from SMEs. Logistics Information Management, 16(5), 312-326. DOI:10.1108/09576050310499318

[71] Shrout, P. E., \& Bolger, N. (2002). Mediation in experimental and nonexperimental studies: New procedures and recommendations. Psychological Methods, 7(4), 422-445. DOI:10.1037/1082989X.7.4.422

[72] Tehseen, S., Ramayah, T., \& Sajilan, S. (2017). Testing and controlling for common method variance: A review of available methods. Journal of Management Sciences, 4(2), 142-168.

[73] Vasiljeva, T., Shaikhulina, S., \& Kreslins, K. (2017). Cloud Computing: Business Perspectives, Benefits and Challenges for Small and Medium Enterprises (Case of Latvia). Procedia Engineering, 178, 443451. DOI:10.1016/j.proeng.2017.01.087

[74] Wang, L., Law, R., Guillet, B. D., Hung, K., \& Fong, D. K. C. (2015). Impact of hotel website quality on online booking intentions: ETrust as a mediator. International Journal of Hospitality Management, 47, 108-115. DOI:10.1016/j.ijhm.2015.03.012

[75] Wangemann, P., Lewis, N., \& Squires, D. A. (2003). Portable Technology Comes of Age. T.H.E. Journal, 31(4), 26-28.

[76] Yasin, M. M., Alavi, J., Czuchry, A., \& Shafieyoun, R. (2014). An exploratory investigation of factors shaping electronic commerce practices in Iran: Benchmarking the role of technology and culture. Benchmarking: An International Journal, 21(5), 775-791. DOI:10.1108/BIJ-12-2012-0086

[77] Yavuz, N., \& Welch, E. W. (2014). Factors affecting openness of local government websites: Examining the differences across planning, finance and police departments. Government Information Quarterly, 31(4), 574-583. DOI:10.1016/j.giq.2014.07.004

[78] Yunis, M. M., Koong, K. S., Liu, L. C., Kwan, R., \& Tsang, P. (2012). ICT maturity as a driver to global competitiveness: A national level analysis. International Journal of Accounting \& Information Management, 20(3), 255-281. DOI:10.1108/18347641211245137

[79] Zaidan, E. (2017). Analysis of ICT usage patterns, benefits and barriers in tourism SMEs in the Middle Eastern countries: The case of Dubai in UAE. Journal of Vacation Marketing, 23(3), 248-263. DOI:10.1177/1356766716654515

[80] Zhu, Y., Basil, D. Z., \& Hunter, M. G. (2009). The extended website stage model: A study of Canadian winery websites. Canadian Journal of Administrative Sciences / Revue Canadienne Des Sciences de I'Administration, 26(4), 286-300. DOI:10.1002/cjas.118

Received: 2021-06-03

Revisions requested: 2021-07-27

Revised: 2021-08-23

Accepted: 2021-10-17
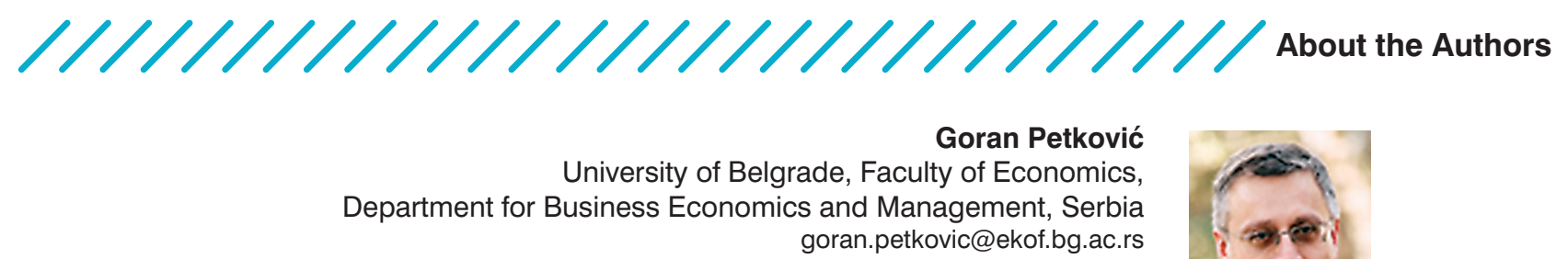

Goran Petković teaches Marketing Channels, Trade Management and Marketing on bachelor, master and PhD levels. He is engaged on the Faculty of Economics, University of Belgrade since 1987, being promoted to full time professor in 2005. He is a Fulbright alumni from 2002, when he implemented research on Zarb School, Hofstra University,

NY. As a member of Supervisory Board in Metalac A.D., Gornji Milanovac, he was reengaged since 2013. In the period from 2007-2013 served as the State secretary in

Government of the Republic of Serbia, in charge of Tourism. Goran Petković is the author of two books (Positioning of trade companies and Models for decision making in trade), co-author of sections in 6 relevant books and author of many chapters in other books and proceedings. Also, he is the author or co-author of more than fifty articles in domestic and international scientific journals.

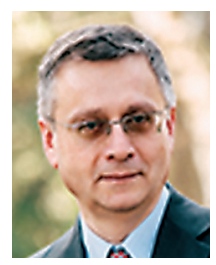




\section{Aleksa Dokić \\ University of Belgrade, Faculty of Economics, Department for Business Economics and Management, Serbia aleksa.dokic@ekof.bg.ac.rs}

Aleksa Dokić is a teaching assistant at the Faculty of Economics, University of Belgrade. He completed his bachelor studies in 2015 , after which he continued his education at the Technical University in Munich (TUM), where in 2017 he earned the M.Sc. degree in Sustainable Resource Management. He obtained his second M.Sc. degree in Trade Sales and Supply Chain Management in 2019, graduating at the Faculty of Economics, University of Belgrade. In 2018 he enrolled in a PhD programme of Business Management at the Faculty of Economics, University of Belgrade. At the bachelor studies level, he currently teaches the courses in Marketing Channels, Trade

Management, Trade Marketing and Sales Management, E-commerce and Customer

Relationship Management. He also teaches the subjects: Principles of Marketing,

Strategy and Core Management Concepts at London School of Economics bachelor programme in Business and Management. His fields of scientific research are eprocurement, e-commerce, omni-channel retail and sustainable resource management.

He participated in many projects in the fields of marketing, corporate management, marketing channels, as well as projects for the Government.

Vladimir Vasić

University of Belgrade, Faculty of Economics, Department for Statistics and Mathematics, Serbia vladimir.vasic@ekof.bg.ac.rs

Vladimir Vasić was born in Belgrade in 1969. He graduated from the Faculty of Economics in 1994, completed a Master course in Statistical Analysis in 1999 and acquired a PhD title in Statistics at the Faculty of Economics in 2003. He is employed as assistant professor at the University of Belgrade - Faculty of Economics (Department of

Statistics and Mathematics) at the courses: Multivariate Analysis, Nonparametric Statistical Methods. He deals with the implementation of data mining and data science in business economics. He is involved in many commercial projects in the region. $\mathrm{He}$ is the author of over 20 papers in journals on the $\mathrm{SCl}$ and $\mathrm{SSCl}$ lists.
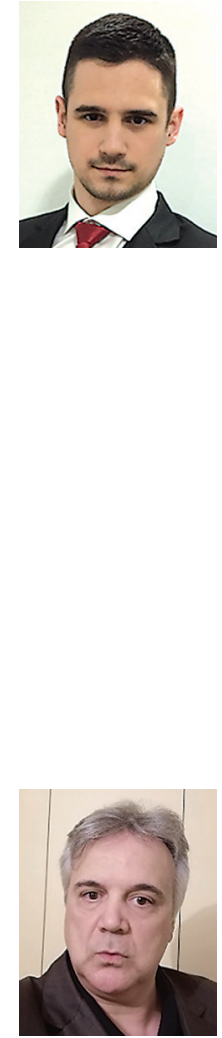